Article

\title{
Corporate Social Responsibility, the Atmospheric Environment, and Technological Innovation Investment
}

\author{
Guichuan Zhou, Lan Zhang and Liming Zhang *(D) \\ Business School, Sichuan University, Chengdu 610065, China; zhouguichuan@scu.edu.cn (G.Z.); \\ z1997405694@163.com (L.Z.) \\ * Correspondence: zhangliming@scu.edu.cn
}

Received: 18 December 2018; Accepted: 15 January 2019; Published: 17 January 2019

\begin{abstract}
Based on the stakeholder theory, this paper takes the 2016 data of China's A-share listed enterprises as a sample. It then uses SPSS 22 to conduct statistical analyses on the sample data to study the relationship between corporate social responsibility (CSR) and technological innovation investment, particularly the role of the atmospheric environment in regulating the relationship between the two. This paper shows that there is a significant positive correlation between CSR and an enterprise's technological innovation investment. Further research has found that in the case of a poor atmospheric environment, the government's environmental regulations have increased the operating costs of enterprises and weakened the intensity of technological innovation investment. However, when there is public pressure, CSR will improve. Consequently, the correlation between CSR and technological innovation investment is weak. In the case of a good atmospheric environment, enterprises do not need to increase their operating costs. To establish a good image and increase profitability, enterprises lean towards fulfilling their social responsibilities and enhancing their investment in technological innovation. This will also boost the positive correlation between CSR and technological innovation investment.
\end{abstract}

Keywords: corporate social responsibility; atmospheric environment; technological innovation investment

\section{Introduction}

The rapid development of the economy has led to the deterioration of the global environment on which the public relies for survival. Consequently, many governments' regulation of resources and the environment is becoming increasingly strict, and the media more frequently report on corporate social responsibility (CSR) in matters such as pollution caused by enterprises [1]. Therefore, the public is also becoming more concerned about CSR. The motivations for enterprises to fulfill their social responsibilities can be summarized into three categories: economic incentives, legal motives and altruism [2]. Enterprises with economic incentives will fulfill their CSR as a competitive strategy, thus gaining an economic advantage in the market [3]. Enterprises with legal motives fulfill their social responsibilities under the regulatory pressure of the institutional environment [4]. Meanwhile, for enterprises with altruism as the motive for fulfilling their social responsibilities, Testa et al. reported that personal values are a key determinant in the performance of CSR; that is, entrepreneurs' personal attitudes are the most important driving factor in enterprises fulfilling their social responsibilities [5].

The atmospheric environment is the first and most direct reflection of the state of the natural environment. From the smog event in London in 1952, to the smog in China today, when the air quality begins to decline, the government and the public will call on enterprises to improve their sense of social responsibility and make more practical contributions to society [6]. Hence, for the 
long-term health of society, enterprises should assume their social responsibilities and effectively reduce environmental pollution through technological innovation [7]. At present, the research on the impact of CSR on enterprises mainly focuses on such factors as financial performance [8], organizational performance [9], employee performance [10] and entrepreneurs' influence [11]. In contrast, there are relatively few studies on the relationship between CSR and technological innovation investment. Existing research shows that under various circumstances, the relationship between CSR and an enterprise's technological innovation behavior will change. [12]. In addition, the results of CSR in different environments are uncertain because the fulfillment of CSR is constrained by its own operations, laws and regulations, and consumer satisfaction. Therefore, it is meaningful to explore the relationship between CSR and technological innovation investment under various atmospheric environment conditions.

The main contributions of this paper are as follows. First, it enriches the literature on CSR from several angles. Previous studies have shown that CSR will affect all aspects of an enterprise. Although CSR and technological innovation investment are beneficial to corporate exports [12], few articles have studied the relationship between CSR and an enterprise's technological innovation investment. This paper takes the 2016 China A-share listed enterprises as a sample to study the relationship between CSR and technological innovation investment. Second, this article focuses on the external air quality surrounding enterprises and studies the role of the atmospheric environment in regulating the relationship between CSR and technological innovation investment.

\section{Theoretical Background and Hypotheses}

Although academics have studied CSR for more than half a century, most research has focused on the impact of CSR on financial performance. In the study of the impact of CSR on corporate financial performance, it is believed that CSR affects the financial performance of enterprises by affecting customer satisfaction, reputation and competitive advantage (innovation) [13]. However, there is less research on the relationship between CSR and an enterprise's technological innovation investment. Based on the following three reasons, the intent of this paper was to study CSR and the technological innovation investment of enterprises. First, an enterprise's technological innovation is a competitive strategy. Therefore, increasing the investment in technological innovation directly affects the technological innovation behavior of enterprises, which can not only increase the profits of enterprises but also enable them to gain competitive advantage [14,15]. Second, an enterprise's technological innovation can provide customers with satisfactory products and services. Therefore, there is a high degree of probability that improving enterprises' technological innovation investment and fulfilling social responsibilities can increase customer satisfaction, and thus enable enterprises to obtain a good market reputation [16]. Third, due to rapid economic growth, the production and management activities of enterprises have damaged the environment. Therefore, improving the investment in technological innovation is also an embodiment of CSR [17].

\subsection{The Relationship Between CSR and Technological Innovation Investment}

From the perspective of stakeholders, CSR refers to the enterprise's social responsibility to its employees, consumers, suppliers, communities and the environment while creating profits and financial liabilities to shareholders [18]. Different stakeholders have different interests in enterprises [19]. For example, shareholders care about the ability of enterprises to create profits, employees want to improve the level of compensation and benefits, consumers expect enterprises to provide safe and reliable products and services, and society is most concerned about whether the operation of enterprises is legal and standardized. Enterprises should also assume responsibility for the environment, provide customers with the products and services they need, and ensure the sustainable development of enterprises and the environment with the least environmental and resource consumption. According to Freeman's stakeholder theory, which was developed in 1984, the development of an enterprise is inseparable from the participation of all stakeholders. Enterprises 
should pursue the overall interests of stakeholders, not just the interests of shareholders. Enterprises must meet the different needs of all stakeholders. Therefore, enterprises need to shoulder their own social responsibilities while also taking economic responsibility.

Enterprises must improve their technological innovation capabilities to meet the diverse needs of their stakeholders. Enterprises can rely on their own strength through technological innovation, in good faith, to obtain innovative results with which to provide consumers with satisfactory products and services while winning market share, increasing corporate income [20] and providing higher compensation for employees. In addition, enterprises can improve existing processes and improve resource utilization through technological innovation, thereby reducing wastage of resources and lightening the environmental burden [21,22]. Porter and Linde found that enterprises that integrate social responsibility into technological innovation will take the initiative in the market, which is one of the means for enterprises to acquire core competitiveness [23]. To achieve the desired technological innovation, enterprises must ensure sufficient investment in technological innovation. However, some scholars believe that there is a negative correlation between CSR and an enterprise's technological innovation investment [24]. Not all CSR behaviors can create value for the business because they increase business costs, even though enterprises can gain a good market reputation. It also reduces the technological innovation investment. However, most scholars believe that when CSR is integrated into corporate strategy, CSR behavior has a positive effect on technological innovation investment $[25,26]$. Moreover, enterprises with higher investment intensity in technological innovation will tend to pay more attention to their CSR behavior [27]. In other words, there is an interaction between CSR and an enterprise's technological innovation investment. As the ecological environment continues to deteriorate, improving the technological innovation capability of enterprises is essential to protect the environment and increase the positive results of innovation. Considering the requirements of all stakeholders, the implementation of CSR should be comprehensive. In addition, enterprises must increase their investment in technological innovation to ensure their own long-term development and that of society as a whole. In view of this discussion, this paper proposes the following hypothesis:

Hypothesis 1: There is a significant relationship between CSR and an enterprise's technological innovation investment, and the two variables change in the same direction.

\subsection{The Regulatory Role of the Atmospheric Environment on the Relationship Between CSR and Technological Innovation Investment}

The concept of CSR was first proposed by the American scholar Clark, who divided CSR into environmental responsibility, employee responsibility, and partner responsibility [28]. With the rise of environmentalism, the focus of CSR has shifted to environmental issues [29]. Although China's economy is developing rapidly, in the initial development stages, enterprises pay attention only to production and the pursuit of economic interests, ignoring their environmental responsibilities. This has led to a rapid deterioration of the Chinese environment and serious atmospheric problems, such as smog and acid rain. These atmospheric problems have seriously damaged the interests of the public. Therefore, to meet the diverse needs of the stakeholders, enterprises can resolve the contradiction between the development of production and the protection of the atmospheric environment by improving their technological innovation capabilities.

The driving force for technological innovation to address atmospheric pollution includes two main aspects. The first aspect is the mandatory environmental regulation by the government [30]. Scholars who support the "Porter Hypothesis" believe that environmental regulation has a positive effect on increasing enterprises' technological innovation investment. Enterprises expect to reduce pollution and improve product quality by increasing investment in technological innovation, thereby reducing production costs and increasing operating income [31]. However, some scholars have raised objections and believe that environmental regulation cannot effectively increase the investment in technological innovation [32-34]. Thus, the "Porter Hypothesis" is not established under any circumstances [35]. 
The second aspect is the spontaneous behavior of enterprises, whereby CSR drives the investment in technological innovation of enterprises [36]. By developing high-technology alternatives or improving resource utilization, enterprises can reduce their consumption of natural resources. This reduces emissions while at the same time improving the enterprise's social reputation and increasing consumer satisfaction [37,38]. Studies have shown that when pollution of the atmosphere rises, the government will tend to strengthen environmental regulation and enterprises will pay more attention to the atmospheric environment for this reason [39]. Furthermore, pollution of the atmosphere will lead consumers to call upon enterprises to strengthen their environmental protection behaviors and strengthen their CSR [40]. Moreover, when the atmospheric environment is poor, the government will introduce strict environmental regulations and policies, and forcefully intervene in the production and environmental protection activities of enterprises by increasing environmental taxes and fines. These kinds of interventions increase the production and operational costs of enterprises [41,42], which weakens the intensity of enterprises' technological innovation investment [43]. Therefore, this paper proposes the following hypothesis:

Hypothesis 2: When the atmospheric environment worsens, the relationship between CSR and technological innovation investment will weaken.

\section{Data, Variables, and Methodology}

\subsection{Data}

The data in this paper were derived from the following pathways. The CSR related data can be obtained from Hexun website; for details, please refer to the Supplementary Materials Section. The data on the enterprises' technological innovation investment and other control variables were derived from the 2016 annual report of enterprises and queried from Wind Info. The initial data on the enterprise's technological innovation investment were derived from the total R\&D expenditure. The data for the atmospheric environment, which is the average number of days with air quality Grade 2 and above in each province, were derived from the 2016 Environmental Status Bulletin of the provincial environmental protection bureaus. In addition, the national average number of days with air quality Grade 2 and above in 2016 comes from the National Bureau of Statistics. The measurement units are all days, and the data are greater than 0 and less than 365 .

This article uses the 2016 A-share listed enterprises from China as a research sample. This sample was screened by excluding the Special treatment sample enterprises and financial industry enterprises. Given that the main business of the technology industry is technological innovation, it is fundamentally different from the technological innovation of other enterprises. Therefore, it was also necessary to exclude enterprises from the technology industry. We also excluded enterprises that did not have any investment in technological innovation and enterprises with a missing CSR index. Finally, there were 2316 enterprises in the 2016 sample. A detailed description of the sample data can be found in Section 4.1.

\subsection{Variables}

\subsubsection{Technological Innovation Investment}

The measurement indicators of technological innovation are roughly divided into three categories: input indicators, process indicators and output indicators [44]. This paper adopted R\&D investment as the evaluation index of technological innovation investment. The disclosure of the sample enterprises' technological innovation investment data mainly appears in the enterprises' annual reports. Through the WIND database, the total amount of technological innovation investment of each enterprise was determined. The technological innovation investment is given in units of one million yuan. 


\subsubsection{CSR}

This paper takes the comprehensive score of the professional evaluation system of China's listed enterprises' social responsibility report released by Hexun.com as a measure of CSR. This measure examines five aspects of CSR: shareholder responsibility, employee responsibility, supplier, customer and consumer rights responsibility, environmental responsibility and social responsibility. Each aspect has 13 secondary indicators and 37 tertiary indicators. Moreover, when enterprises in different industries are evaluated, the weight ratios of the various parts will differ. Therefore, it is possible to conduct a comprehensive evaluation of the social responsibilities of various enterprises, and this technique has been widely applied in related research in recent years [2,45].

\subsubsection{Atmospheric Environment}

Drawing on the practices of previous scholars, we used the following proxy variables for the atmospheric environment [46]: the average number of days in each province in 2016 that had an air quality of Grade 2 and above, and the average number of days nationally in 2016 that had an air quality of Grade 2 and above. When the average number of days in each province was higher than the average number of days in the country, then the atmosphere in the provinces in which the enterprises were located was good. Meanwhile, when the average number of days in each province was lower than the average number of days in the country, then the enterprises in the provinces faced a poor atmospheric environment.

\subsubsection{Control Variables}

Existing research has found that organizational characteristics-such as an enterprise's financial status and the nature of their business - can affect CSR and technological innovation investment [2,47]. Therefore, this paper controls these variables and adds two financial indicators: the debt asset ratio (DAR) and return on equity (ROE). The nature of enterprises (STATE) was 1 for state-owned enterprises and 0 for other properties.

\subsection{Methodology}

This paper used SPSS 22 to carry out the statistical analysis [1] of the data from 2016. A-share listed enterprises in China were used to test the two hypotheses proposed in this paper. The model depicted in Figure 1 was built to test research Hypothesis 1 which asks whether CSR will increase the corporate's technological innovation investment (Inno) and form a major driving force for enterprises to implement the innovation strategy.

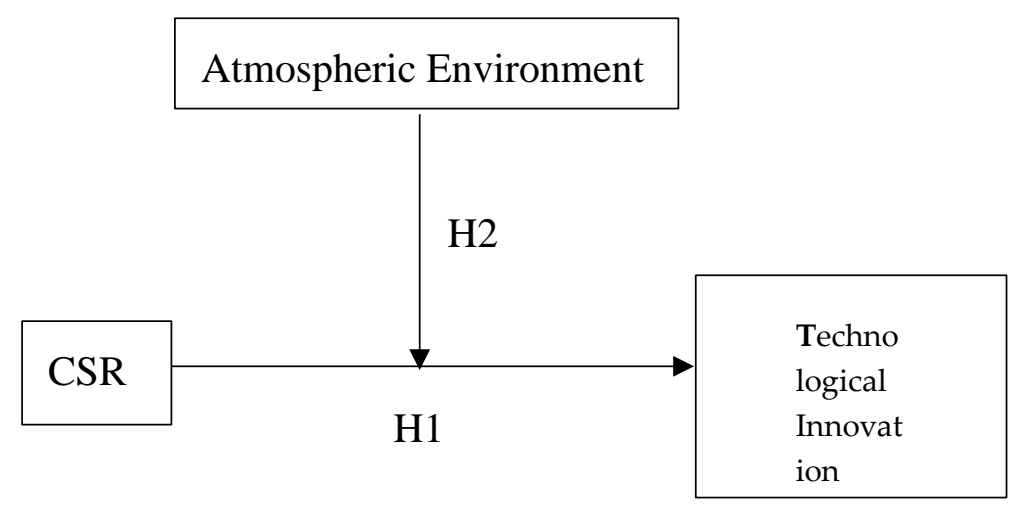

Figure 1. Research model map.

According to Hypothesis 1, the correlation coefficient between CSR and technological innovation investment was expected to be significantly greater than 0 . This paper grouped enterprises according to the good or poor conditions of the atmospheric environment. It then tested the relationship between 
CSR and technological innovation investment under different atmospheric environment conditions. The results of our model in different grouping cases were then compared to verify Hypothesis 2 .

\section{Results and Discussion}

\subsection{Variable Descriptive Analysis}

Table 1 shows the descriptive statistics of the variables. The average CSR, Envi, DAR, and ROE of the sample firms are close to the median, which indicates that the sample tended to be normally distributed in terms of the basic characteristics. Some further observations of the sample characteristics of technological innovation investment and CSR follow in Tables 2 and 3. As can be seen from Table 2, enterprises engaged in technological innovation investment were concentrated in the construction, manufacturing, and information transfer, software and information technology service industries. The construction industry had the highest average technological innovation investment. As can be seen from Table 3, enterprises with higher CSR indices were mainly subordinate to public health and social work, real estate, transport, warehousing and postal, and cultural, sports and recreational industries. Although the number of manufacturing enterprises was the largest, the average CSR index of enterprises in this industry was not high — and was actually far lower than the average CSR index of most tertiary industries.

Table 1. Descriptive statistics of the main variables.

\begin{tabular}{ccccccc}
\hline Variable & $\mathbf{N}$ & Max & Min & Mean & Median & sd \\
\hline Inno & 2316 & 12762.1 & 0.0047 & 178.799 & 52.489 & 460345.247 \\
CSR & 2316 & 87.25 & -18.18 & 27.23 & 22.52 & 309.009 \\
Envi & 2316 & 363.0 & 196.0 & 279.186 & 283.0 & 2493.237 \\
DAR & 2316 & 1.003 & 0.017 & 0.386 & 0.368 & 0.038 \\
ROE & 2316 & 0.741 & -2.474 & 0.082 & 0.07675 & 0.012 \\
STATE & 2316 & 1 & 0 & 0.28 & 0.00 & 0.201 \\
\hline
\end{tabular}

Table 2. Description of industry characteristics of the enterprises' technological innovation investment.

\begin{tabular}{|c|c|c|c|c|c|}
\hline Industry & $\mathbf{N}$ & Mean & Max & Min & Median \\
\hline Mining industry & 32 & 103.39 & 644 & 0.471 & 45.933 \\
\hline $\begin{array}{c}\text { Electricity, heat, gas, water production and } \\
\text { supply industry }\end{array}$ & 21 & 16.558 & 96.505 & 0.21 & 10.28 \\
\hline Real estate industry & 9 & 16.306 & 50.516 & 2.181 & 12.747 \\
\hline Construction industry & 52 & 1047.55 & 10592.471 & 2.983 & 83.74 \\
\hline Transport, warehousing and postal industries & 24 & 18.589 & 73.159 & 0.684 & 8.354 \\
\hline Education & 1 & 22.1114 & 22.1114 & 22.1114 & 22.1114 \\
\hline $\begin{array}{c}\text { Agriculture, forestry, animal husbandry and } \\
\text { fishery industries }\end{array}$ & 20 & 31.2 & 223.792 & 1.262 & 16.263 \\
\hline Wholesale and retailing industry & 33 & 53.645 & 386.098 & 0.598 & 32.757 \\
\hline $\begin{array}{l}\text { Water resources, environment and public } \\
\text { facilities industries }\end{array}$ & 15 & 39.557 & 75.432 & 16.01 & 42.59 \\
\hline Public health and social work & 2 & 72.28 & 102.7 & 41.86 & 72.28 \\
\hline Cultural, sports and recreational industries & 17 & 88.08 & 613.611 & 1.484 & 35.585 \\
\hline $\begin{array}{l}\text { Information transfer, and software and } \\
\text { information technology service industry }\end{array}$ & 138 & 121.89 & 1351.275 & 0.018 & 69.214 \\
\hline Manufacturing industry & 1235 & 128.882 & 12762.1 & 0.405 & 49.355 \\
\hline Comprehension & 8 & 35.011 & 117.891 & 5.481 & 20.538 \\
\hline Leasing and commercial service industry & 15 & 32.38 & 229 & 2.852 & 12.637 \\
\hline total & 2316 & 178.799 & 12762.1 & 0.0047 & 52.489 \\
\hline
\end{tabular}


Table 3. Description of industry characteristics of corporate social responsibility (CSR).

\begin{tabular}{|c|c|c|c|c|c|}
\hline Industry & $\mathbf{N}$ & Mean & Max & Min & Median \\
\hline Mining industry & 32 & 103.39 & 644 & 0.471 & 45.933 \\
\hline $\begin{array}{c}\text { Electricity, heat, gas, water production and } \\
\text { supply industry }\end{array}$ & 21 & 16.558 & 96.505 & 0.21 & 10.28 \\
\hline Real estate industry & 9 & 16.306 & 50.516 & 2.181 & 12.747 \\
\hline Construction industry & 52 & 1047.55 & 10592.471 & 2.983 & 83.74 \\
\hline Transport, warehousing and postal industries & 24 & 18.589 & 73.159 & 0.684 & 8.354 \\
\hline Education & 1 & 22.1114 & 22.1114 & 22.1114 & 22.1114 \\
\hline $\begin{array}{c}\text { Agriculture, forestry, animal husbandry and } \\
\text { fishery industries }\end{array}$ & 20 & 31.2 & 223.792 & 1.262 & 16.263 \\
\hline Wholesale and retailing industry & 33 & 53.645 & 386.098 & 0.598 & 32.757 \\
\hline $\begin{array}{l}\text { Water resources, environment and public } \\
\text { facilities industries }\end{array}$ & 15 & 39.557 & 75.432 & 16.01 & 42.59 \\
\hline Public health and social work & 2 & 72.28 & 102.7 & 41.86 & 72.28 \\
\hline Cultural, sports and recreational industries & 17 & 88.08 & 613.611 & 1.484 & 35.585 \\
\hline $\begin{array}{l}\text { Information transfer, and software and } \\
\text { information technology service industry }\end{array}$ & 138 & 121.89 & 1351.275 & 0.018 & 69.214 \\
\hline Manufacturing industry & 1235 & 128.882 & 12762.1 & 0.405 & 49.355 \\
\hline Comprehension & 8 & 35.011 & 117.891 & 5.481 & 20.538 \\
\hline Leasing and commercial service industry & 15 & 32.38 & 229 & 2.852 & 12.637 \\
\hline total & 2316 & 178.799 & 12762.1 & 0.0047 & 52.489 \\
\hline
\end{tabular}

\subsection{Correlation Analysis}

Table 4 shows the correlation test results for the main variables. These results show that there was a significant positive relationship between CSR and technological innovation investment. Therefore, Hypothesis 1 was initially verified. Furthermore, there was no serious multicollinearity problem between the rest of the control variables and an enterprise's technological innovation investment and CSR, and the model parameters were reasonable.

Table 4. Correlation analysis between variables.

\begin{tabular}{ccccccc}
\hline & Inno & CSR & Envi & DAR & ROE & STATE \\
\hline Inno & & $0.183^{* * *}$ & $-0.053^{* *}$ & $0.267^{* * *}$ & $0.138^{* * *}$ & $0.13^{* * *}$ \\
CSR & $0.102^{* * *}$ & & 0.013 & $-0.078^{* * *}$ & $0.496^{* * *}$ & $0.064^{* * *}$ \\
Envi & $-0.079^{* * *}$ & -0.004 & & -0.034 & $0.042^{* * *}$ & $-0.115^{* * *}$ \\
DAR & $0.215^{* * *}$ & $0.028^{* * *}$ & -0.04 & & $-0.097^{* * *}$ & $0.328^{* * *}$ \\
ROE & $0.038^{* * *}$ & $0.242^{* * *}$ & $0.022^{* * *}$ & $-0.122^{* * *}$ & & $-0.157^{* * *}$ \\
STATE & $0.145^{* * *}$ & $0.151^{* * *}$ & $-0.115^{* * *}$ & $0.341^{* * *}$ & $-0.135^{* * *}$ & \\
\hline
\end{tabular}

Note: Spearman correlation coefficients are shown in the area above the diagonal and Pearson correlation coefficients are shown in the area below the diagonal; ***,** and * indicate the significance level is $1 \%, 5 \%$, and $10 \%$, respectively.

\subsection{Empirical Statistical Results}

\subsubsection{The Relationship Between CSR and Technological Innovation Investment}

The model was first statistically analyzed, mainly to determine the relationship between CSR and technological innovation investment. The statistical results in Table 5 show that the coefficient of influence was 2.868, which was significant at the $1 \%$ level. That is to say, under the influence of certain factors, CSR and enterprises' technological innovation investment were significantly correlated; they both changed in the same direction, and they had a significant positive relationship. Moreover, as shown in Table 5, there was also a correlation between DAR/ROE/STATE and technological innovation investment, which were all significant at the $1 \%$ level. This shows that the level of corporate profitability and the nature of enterprises will affect the enterprise's technological innovation behavior of enterprises. Therefore, Hypothesis 1 is verified. 
Table 5. The relationship between CSR and technological innovation investment.

\begin{tabular}{ccc}
\hline Independent Variable & Technological Innovation Investment \\
\hline CSR & $2.793^{* * * *}$ & $(3.422)$ \\
DAR & $668.792^{* * * *}$ & $(8.993)$ \\
ROE & $330.766^{* * *}$ & $(2.563)$ \\
STATE & $114.750^{* * * *}$ & $(3.461)$ \\
Constant term & $-214.438^{* * *}$ & $(-5.712)$ \\
N & $2316^{*}$ & \\
R2 & 0.062 & \\
F & 38.185 & \\
\hline
\end{tabular}

Note: ${ }^{*} p<0.1,{ }^{* *} p<0.05,{ }^{* * *} p<0.01$; the $t$ value of the corresponding coefficient is shown in parentheses.

\subsubsection{Influence of the Atmospheric Environment on CSR and Technological Innovation Investment}

Our research found that CSR and enterprises' technological innovation investment changed in the same direction. Furthermore, CSR is the result of a combination of internal and external environmental impacts, especially as the global environment deteriorates and governments tighten their environmental regulations. The state of the atmospheric environment in which enterprises were located also directly and indirectly affected CSR and technological innovation. Because the internal and external environments affect corporate decision-making, CSR and the atmospheric environment, both affect the enterprise's technological innovation investment of enterprises. Consequently, this paper studied the associated relationship between CSR and technological innovation investment under different atmospheric environment conditions.

In the statistical analysis results for technological innovation investment (Table 6), it can be seen that under different atmospheric environment conditions, corporate social responsibility and enterprise technology innovation investment have a significant positive relationship. Under different atmospheric environment conditions, the statistical relationship between CSR and technological innovation investment is significant at the level of $1 \%$ and $10 \%$, respectively. In the case of poor atmospheric environment, the relationship between CSR and technological innovation investment was weaker. In the case of a good atmospheric environment, CSR and technological innovation investment were more closely related and more significant, which validates Hypothesis 2.

Table 6. The relationship between CSR and technological innovation investment under different atmospheric environment conditions.

\begin{tabular}{ccccc}
\hline Independent Variable & \multicolumn{2}{c}{ Good Atmospheric Environment } & \multicolumn{2}{c}{ Poor Atmospheric Environment } \\
\hline CSR & $2.811^{* * *}$ & $(3.183)$ & $2.427^{*}$ & $(1.788)$ \\
DAR & $485.985^{* * *}$ & $(5.948)$ & $814.528^{* * *}$ & $(6.705)$ \\
ROE & $87.194^{* * *}$ & $(0.677)$ & $646.512^{* * *}$ & $(2.754)$ \\
STATE & -4.875 & $(0.898)$ & $186.787^{* * *}$ & $(3.517)$ \\
Constant term & $-126.447^{* * *}$ & $(-3.037)$ & $-282.699^{* * *}$ & $(-4.67)$ \\
N & $1130^{* *}$ & & 1186 & \\
R2 & 0.042 & & 0.08 & \\
F & 12.288 & & 25.575 & \\
\hline
\end{tabular}

Note: ${ }^{*} p<0.1,{ }^{* *} p<0.05,{ }^{* * *} p<0.01$; the $t$ value of the corresponding coefficient is shown in parentheses.

\subsection{Robustness Examination}

First, this paper guarantees the validity of the sample enterprises. There were some industries that were not meaningful to this research. Consequently, the financial industry, and scientific research and technology services were excluded during the sample selection process. To ensure the effectiveness of the sample enterprises, we also excluded industries that did not have technological innovation investment data (e.g., education, and accommodation and catering). 
Second, this paper guarantees the availability and validity of the data. However, because the National Bureau of Statistics of the People's Republic of China has not yet released the atmospheric environment data for 2017, we were unable to obtain relevant and accurate data and information on the current atmospheric environment. Moreover, the Ministry of Environmental Protection of China released its newly revised "Environmental Air Quality Standards" in 2013, resulting in a shortage of data for some provinces and cities in 2013 and 2014. Therefore, the 2016 data are more comprehensive and more reflective of the status quo. Therefore, the 2016 atmospheric environmental data, the CSR index and technological innovation investment were used for our research.

Finally, in order to verify the robustness of the statistical analysis results and drawing on the research of Huang et al. [48], this paper excludes the samples of non-manufacturing enterprises, and only analyzes the relevant data of manufacturing enterprises. China has long been engaged in the production of labor-intensive products, especially in the manufacturing sector, where the degree of environmental pollution is more serious. Consequently, manufacturing enterprises have greater social responsibilities and, therefore, we are more concerned about the relationship between manufacturing CSR and technological innovation investment. The sample of manufacturing enterprises accounted for $74.53 \%$ of the total sample of A-share listed enterprises in 2016. Excluding the sample of manufacturing enterprises, the results showed that the coefficient of return of manufacturing CSR to technological innovation investment was greater. Moreover, the results showed that in the case of a good atmospheric environment, the social responsibility of manufacturing enterprises was more closely related to their investment in technological innovation.

\subsection{Discussion of Statistical Results}

This paper used data from China's listed A-share enterprises in 2016 to analyze the relationship between CSR and technological innovation investment under different atmospheric environment conditions. Table 5 shows that CSR and technological innovation investment have a significant positive relationship. Considering the influence of the external factors of the atmospheric environment, when the atmospheric environment in which enterprises are located was poor, the positive correlation between CSR and technological innovation investment was relatively weak. However, when the atmospheric environment was good, CSR and technological innovation investment were more closely related. In other words, in the case of a poor atmospheric environment, the positive correlation between CSR and technological innovation investment was weaker than when the atmospheric environment was good.

When the atmospheric environment is poor, the government will tend to strengthen its environmental regulation of enterprises. The most direct behavior is to increase the environmental tax on enterprises to force them to meet environmental requirements. Yu et al. [49] proposed that an environmental tax can effectively increase the technological innovation investment of enterprises but also has a threshold effect. Only when the environmental tax is greater than the threshold will it promote enterprises' investment in technological innovation. However, most enterprises around the world have not yet reached this threshold. Therefore, as a whole, the cost of compliance with environmental regulations will affect the enterprises' investment in technological innovation [34]. This shows that the current cost-effectiveness of the government's environmental regulation exceeds the compensation effect of innovation [32,33]. In comparison, a good atmospheric environment will weaken the investment in technological innovation.

Previous studies have shown that CSR has a positive impact on reducing pollution, and this influence is reinforced when environmental regulation is developed [50]. Therefore, many governments have attempted to create more sensitive environments with regard to social and environmental problems, and they have sent signals to corporations that they should strengthen their commitment to environmental issues [51]. By including CSR in the law, the government can more effectively supervise CSR and can better motivate enterprises to fulfill their environmental protection responsibilities. However, enterprises are forced to increase their social responsibility expenditure and increase their 
operating costs, which will also weaken their investment in technological innovation [52]. Moreover, not only does the government require enterprises to strengthen their social responsibilities but social concerns will also require them to pay more attention to CSR [2]. Air pollution from an enterprise's emissions tends to be included as one of the key negative components of their social and environmental behavior [53]. When the atmospheric environment deteriorates, the public pressure faced by enterprises will also increase. Consequently, enterprises must strengthen their social responsibilities if they wish to establish a good image [38]. Therefore, when the atmospheric environment is poor, the relationship between CSR and technological innovation investment will be weaker. Meanwhile, when the atmospheric environment is good, enterprises face fewer and less stringent environmental regulations, thus reducing their operating costs. Consequently, these enterprises will increase the investment in technological innovation.

Moreover, due to the government's and the public's emphasis on the environment and the transformation of business philosophy [54,55], many enterprises no longer simply pay attention to economic benefits, but they also now regard environmental protection as one of their key development tasks [56]. Most companies have begun to pay attention to fulfilling their social responsibilities, and they pursue the sustainable development of their enterprises and of society as a whole. Therefore, when the atmospheric environment is better, CSR and technological innovation investment are more closely related. That is to say, in the case of a poor atmospheric environment, the positive correlation between CSR and technological innovation investment is weaker than when the atmospheric environment is good.

\section{Conclusions}

Our discussion and analysis of the empirical results lead to the following recommendations.

First, the management of the atmospheric environment should be strengthened. The rapid economic growth of countries around the world has been achieved at the expense of the huge consumption of environmental and non-renewable resources. With the rapid deterioration of the atmospheric environment, governments and the public have fully realized the seriousness of this problem. Even after the joint efforts of various countries, although the atmospheric environment has improved, the atmospheric environment of some countries and regions is still very poor. Furthermore, some enterprises in developed countries have relocated many of their polluting factories to developing countries such as China and India, where the labor costs are low, and consequently the atmospheric pollution in these countries is very serious. Therefore, governments should strengthen their efforts in environmental regulation, and should supervise and manage the production behavior of enterprises in a timely way. In addition, enterprises should also actively respond to the environmental systems and policies proposed by the government. They should also pursue the goal of sustainable development, take the initiative to undertake social responsibilities, and actively carry out technological innovation and improve processes to reduce pollution and the waste of resources. In addition, the public and the media should also pay attention to the atmospheric environment in which they are located, and should urge enterprises to fulfill their social responsibilities and work together to manage the atmospheric environment.

Second, the management of CSR should be strengthened. CSR clearly has a positive role to play in protecting the environment and promoting the healthy development of enterprises. By fulfilling their social responsibilities, enterprises can reduce the waste of resources in the production process, increase the governance of the already damaged environment and greatly reduce the damage to the environment during the whole business operation. They can also create a good corporate image by satisfying the different needs of stakeholders, create a responsible corporate brand and convert the cost of fulfilling CSR into marketing expenditure and increase revenue.

Third, environmental regulation policies should be optimized. In recent years, many governments have formulated strict environmental regulation policies and increased environmental governance, so the air quality of most countries has improved. However, the current environmental regulation 
policy has brought additional costs to enterprises, hindered technological innovation of enterprises and limited the development of enterprises. Therefore, it is recommended that the government should adjust existing environmental regulation policies and re-establish appropriate environmental regulation policies based on a full understanding of the threshold effect. This will lead to an environmental regulation policy that will not only inhibit the polluting behavior of enterprises, but also encourage enterprises to increase investment in technological innovation.

Finally, this paper has observed the following limitations, which need further research. First of all, due to the limitations of our data, this paper selected the 2016 data of China's A-share listed enterprises and the atmospheric environment for research, which means that there are shortcomings in timeliness. Therefore, it is recommended that further work should be done to improve the data collection method and use the latest data from the authoritative source. In addition, given that China's environmental management standards before 2013 are different from the present standards, time series verification is not possible and, therefore, it is necessary to verify the conclusions of this paper in the future. Finally, this paper uses air quality, that all enterprises will face, to measure the atmospheric environment. Consequently, further research should study the adjustment effect of other variables on CSR and technological innovation investment.

Supplementary Materials: The CSR data are available online at http://stockdata.stock.hexun.com/zrbg/Plate. aspx?date $=2016-12-31$.

Author Contributions: The authors contributed equally to this work. All authors read and approved the final manuscript.

Funding: This research was funded by the National Natural Science Foundation of China, grant number 71702118 .

Conflicts of Interest: The authors declare no conflict of interest.

\section{References}

1. Wang, Y.; Li, Y.X.; Ma, Z.; Song, J.B. Media attention, environmental regulation and corporate environmental protection investment. Nankai Manag. Rev. 2017, 20, 83-94.

2. Jia, X.P.; Liu, Y. External Environment, Internal Resources and Corporate Social Responsibility. Nankai Manag. Rev. 2014, 17, 13-18.

3. Flammer, C. Does product market competition foster corporate social responsibility? Strateg. Manag. J. 2015, 36, 1469-1485. [CrossRef]

4. Zhai, L.Z.; Wang, L.; Liu, Y. Research on the Influence of External Environmental Factors on the Social Responsibility of Small Enterprises. Soft Sci. 2016, 30, 69-73. [CrossRef]

5. Testa, F.; Gusmerottia, N.M.; Corsini, F.; Passetti, E.; Iraldo, F. Factors Affecting Environmental Management by Small and Micro Firms: The Importance of Entrepreneurs' Attitudes and Environmental Investment. Corp. Soc. Responsib. Environ. Manag. 2016, 23, 373-385. [CrossRef]

6. Espinoza, M.J.P.; Carrion, C.E.; Mocha, B.P. Corporate social responsibility and environmentalapproach: A sustainable vision to the future. Rev. Univ. Y Soc. 2016, 8, 169-178.

7. Li, H.Z.; Zeng, E.Y.; You, J. Mitigating pesticide pollution in China requires law enforcement, farmer training, and technological innovation. Environ. Toxicol. Chem. 2014, 33, 963-971. [CrossRef] [PubMed]

8. Flammer, C. Does Corporate Social Responsibility Lead to Superior Financial Performance? A Regression Discontinuity Approach. Manag. Sci. 2015, 61, 2549-2568. [CrossRef]

9. Petrenko, O. Corporate social responsibility or CEO narcissism? CSR motivations and organizational performance. Strateg. Manag. J. 2016, 37, 262-279. [CrossRef]

10. Korschun, D. Corporate Social Responsibility, Customer Orientation, and the Job Performance of Frontline Employees. J. Mark. 2014, 78, 20-37. [CrossRef]

11. Tang, Y. How CEO hubris affects corporate social (ir)responsibility. Strateg. Manag. J. 2015, 36, 1338-1357. [CrossRef]

12. González-Ramos, M.; Donate, M.J.; Guadamillas, F. An empirical study on the link between corporate social responsibility and innovation in environmentally sensitive industries. Eur. J. Int. Manag. 2018, 12, 402-422. [CrossRef] 
13. Saeidi, S.P.; Sofian, S.; Saeidi, P. How does corporate social responsibility contribute to firm financial performance? The mediating role of competitive advantage, reputation, and customer satisfaction. J. Bus. Res. 2015, 68, 341-350. [CrossRef]

14. Jaklic, M.; Cerne, M.; Skerlavaj, M. Management innovation enters the game: Re-considering the link between technological innovation and financial performance. Innovation 2015, 17, 429-449. [CrossRef]

15. Coccia, M. Sources of technological innovation: Radical and incremental innovation problem-driven to support competitive advantage of firms. Technol. Anal. Strateg. Manag. 2017, 29, 1048-1061. [CrossRef]

16. Fuentes-Blasco, M.; Moliner-Velazquez, B.; Servera-Frances, D.; Gil-Saura, I. Role of marketing and technological innovation on store equity, satisfaction and word-of-mouth in retailing. J. Prod. Brand Manag. 2017, 26, 650-666. [CrossRef]

17. Oginni, O.S.; Omojowo, A.D. Sustainable Development and Corporate Social Responsibility in Sub-Saharan Africa: Evidence from Industries in Cameroon. Economies 2016, 4, 10. [CrossRef]

18. Clarkson, M.E. A Stakeholder Framework for Analyzing and Evaluating Corporate Social Performance. Acad. Manag. Rev. 1995, 20, 92-117. [CrossRef]

19. Jia, X.P.; Liu, Y.; Liao, Y.H. Stakeholder pressure, corporate social responsibility and corporate value. Chin. J. Manag. 2016, 13, 267. [CrossRef]

20. Laforet, S. Organizational innovation outcomes in SMEs: Effects of age, size, and sector. J. World Bus. 2013, 48, 490-502. [CrossRef]

21. Cavallo, E.; Ferrari, E.; Bollani, L.; Coccia, M. Strategic management implications for the adoption of technological innovations in agricultural tractor: The role of scale factors and environmental attitude. Technol. Anal. Strateg. Manag. 2014, 26, 765-779. [CrossRef]

22. Santana, N.B.; Rebelatto, D.A.D.; Perico, A.; Moralles, H.F.; Leal, W. Technological innovation for sustainable development: An analysis of different types of impacts for countries in the BRICS and G7 groups. Int. J. Sustain. Dev. World Ecol. 2015, 22, 425-436. [CrossRef]

23. Michael, E.P.; Claas, V.D.L. Toward a New Conception of the Environment-Competitiveness Relationship. J. Econ. Perspect. 1995, 9, 97-118.

24. Gallego-Álvarez, I.; Prado-Lorenzo, J.M.; García-Sánchez, I.-M. Corporate social responsibility and innovation: A resource-based theory. Manag. Decis. 2011, 49, 1709-1727. [CrossRef]

25. Rachel, B.; Christian, L.B.; Caroline, M.; Nicolas, P. Are firms with different CSR profiles equally innovative? An empirical analysis with survey data. Eur. Manag. J. 2013, 31, 642-654. [CrossRef]

26. Maria, G.R.; Mario, D.; Maria, F.G.R. Technological Posture and Corporate Social Responsibility: Effects on Innovation Performance. Environ. Eng. Manag. J. 2014, 13, 2497-2505.

27. Brammer, S.; Millington, A. Does it pay to be different? An analysis of the relationship between corporate social and financial performance. Strateg. Manag. J. 2008, 29, 1325-1343. [CrossRef]

28. Clark, J.M. The Changing Basis of Economic Responsibility. J. Polit. Econ. 1916, 24, 209-229. [CrossRef]

29. Jiang, W.Y.; Wong, J.K.W. Key activity areas of corporate social responsibility (CSR) in the construction industry: A study of China. J. Clean. Prod. 2016, 113, 850-860. [CrossRef]

30. Yuan, B.L.; Ren, S.G.; Hu, X.; Yang, X.Y. The Difference Effect of Environmental Regulation on Two Stages of Technology Innovation in China's Manufacturing Industry. Front. Eng. Manag. 2016, 3, 24-29. [CrossRef]

31. Costantini, V.; Mazzanti, M. On the green and innovative side of trade competitiveness? The impact of environmental policies and innovation on EU exports. Res. Policy 2012, 41, 132-153. [CrossRef]

32. Kneller, R.; Manderson, E. Environmental regulations and innovation activity in UK manufacturing industries. Resour. Energy Econ. 2012, 34, 211-235. [CrossRef]

33. Sen, S. Corporate governance, environmental regulations, and technological change. Eur. Econ. Rev. 2015, 80, 36-61. [CrossRef]

34. Yuan, B.L. Does the "unlocking" of the system and technology drive the green development of China's manufacturing industry? China Popul. Resour. Environ. 2018, 28, 117-127. [CrossRef]

35. Zhang, C.Y.; Lv, Y. Green Production Regulation and Enterprise R\&D Innovation-Influence and Mechanism Research. Econ. Manag. 2018, 40, 71-91. [CrossRef]

36. Borger, F.G.; Kruglianskas, I. Corporate social responsibility and environmental and technological innovation performance: Case studies of Brazilian companies. Int. J. Technol. Policy Manag. 2006, 6, 399-412. [CrossRef]

37. Frank, M.; Robert, S.; Ram, N. An examination of corporate reporting, environmental management practices and firm performance. J. Oper. Manag. 2007, 25, 998-1014. [CrossRef] 
38. Aguilera-Caracuel, J.; Guerrero-Villegas, J. How Corporate Social Responsibility Helps MNEs to Improve their Reputation. The Moderating Effects of Geographical Diversification and Operating in Developing Regions. Corp. Soc. Responsib. Environ. Manag. 2018, 25, 355-372. [CrossRef]

39. Stefano, F.; Eugenio, D.; Daniela, C.; Silvia, S. Does environmental performance affect companies' environmental disclosure? Meas. Bus. Excell. 2015, 19, 42-57. [CrossRef]

40. Ju, S.; Chung, M.S. Evaluation of corporate social responsibility activities for fashion company's sustainable management: On the moderating effects of consumers' perceived fit and motivation. Res. J. Costume Cult. 2015, 23, 644-660. [CrossRef]

41. Jaffe, A.B.; Robert, N.S. Dynamic Incentives of Environmental Regulations: The Effects of Alternative Policy Instruments on Technology Diffusion. J. Environ. Econ. Manag. 1995, 29, S43-S63. [CrossRef]

42. Zhang, P.; Zhang, P.P.; Cai, G.Q. Comparative Study on the Impact of Different Types of Environmental Regulation on Enterprises' Technological Innovation. China Popul. Resour. Environ. 2016, 26, 8-13. [CrossRef] [PubMed]

43. Cao, Y.H.; You, J.X. The contribution of environmental regulation to technological innovation and quality competitiveness an empirical study based on Chinese manufacturing enterprises. Chin. Manag. Stud. 2017, 11, 51-71. [CrossRef]

44. Duan, W.; Jiang, T.W.; Zhang, J.Y.; Wang, G.L. Research on the Evaluation of Technological Innovation Development of Regional Enterprises-Analysis of the Evaluation Index System of Technological Innovation of Zhejiang Province, 11 Districts and Cities and Enterprises. China Soft Sci. 2014, 5, 85-96.

45. Wang, Q.G.; Xu, X.Y. The Value Creation Mechanism and Empirical Test of Corporate Social ResponsibilityBased on Stakeholder Theory and Life Cycle Theory. China Soft Sci. 2016, 2, 179-192.

46. Lin, X.Q.; Wang, D. Temporal and spatial evolution characteristics and socio-economic driving forces of urban air quality in China. J. Geogr. Sci. 2016, 26, 1533-1549. [CrossRef]

47. Halme, M.; Korpela, M. Responsible Innovation toward Sustainable Development in Small and Medium-Sized Enterprises: A Resource Perspective. Bus. Strategy Environ. 2014, 23, 547-566. [CrossRef]

48. Huang, W.; Chen, W. Foreign capital entry, supply chain pressure and Chinese CSR. Manag. World 2015, 2, 91-100.

49. Yu, L.C.; Zhang, W.G.; Bi, Q. Research on the Innovation Effect of Environmental Tax. J. Yunnan Univ. Financ. Econ. 2018, 34, 78-90. [CrossRef]

50. Jimenez-Parra, B.; Alonso-Martinez, D.; Godos-Diez, J.L. The influence of corporate social responsibility on air pollution: Analysis of environmental regulation and eco-innovation effects. Corp. Soc. Responsib. Environ. Manag. 2018, 25, 1363-1375. [CrossRef]

51. Li, D.; Cao, C.; Zhang, L.; Chen, X.; Ren, S.; Zhao, Y. Effects of corporate environmental responsibility on financial performance: The moderating role of government regulation and organizational slack. J. Clean. Prod. 2017, 166, 1323-1334. [CrossRef]

52. Shin, J.Y.; Jung, M.; Khoe, K.I.; Chae, M.S. Effects of Government Involvement in Corporate Social Responsibility: An Analysis of the Indian Companies Act, 2013. Emerg. Mark. Financ. Trade 2015, 51, 377-390. [CrossRef]

53. Liang, H.; Renneboog, L. On the foundations of corporate social responsibility. J. Financ. 2017, 72, 853-910. [CrossRef]

54. Park, B.I.; Ghauri, P.N. Determinants influencing CSR practices in small and medium sized MNE subsidiaries: A stakeholder perspective. J. World Bus. 2015, 50, 192-204. [CrossRef]

55. Vashchenko, M. An external perspective on CSR: What matters and what does not? Bus. Ethics Eur. Rev. 2017, 26, 396-412. [CrossRef]

56. Qi, G.Y.; Zeng, S.X.; Tam, C.M.; Yin, H.T.; Zou, H.L. Stakeholders' Influences on Corporate Green Innovation Strategy: A Case Study of Manufacturing Firms in China. Corp. Soc. Responsib. Environ. Manag. 2013, 20,1-14. [CrossRef]

(c) 2019 by the authors. Licensee MDPI, Basel, Switzerland. This article is an open access article distributed under the terms and conditions of the Creative Commons Attribution (CC BY) license (http://creativecommons.org/licenses/by/4.0/). 